\title{
TINGKAT PEMAHAMAN SISWA KELAS X DALAM PEMBELAJARAN DARING PENDIDIKAN JASMANI DI SMAN 2 CIKARANG PUSAT
}

\author{
Ricky Fauzi ${ }^{1}$, Irfan Zinat Achmad ${ }^{2}$, Aria Kusuma Yuda R ${ }^{3}$ \\ ${ }^{1}$ Program Studi Pendidikan Jasmani Kesehatan Dan Rekreasi \\ Fakultas Keguruan Dan Ilmu Pendidikan, Universitas Singaperbangsa Karawang \\ Rickyfauzi21.rf@gmail.com/
}

\begin{abstract}
ABSTRAK
Penelitian ini dilarbelakangi oleh tidak adanya pembelajaran teori dikelas yang dikhususkan untuk pendidikan jasmani, dan waktu pembelajaran yang sangat minim sehingga siswa sulit memahami pembelajaran pendidikan jasmani. Penelitian ini bertujuan untuk mengetahui tingkat pemahaman siswa kelas $\mathrm{X}$ dalam pembelajaran daring pendidikan jasmani di SMAN 2 Cikarang Pusat. Penelitian ini merupakan penelitian deskriptif kuantitatif, metode yang digunakan adalah survey. Teknik pengumpulan data berupa angket menggunakan tes soal pilihan ganda. Populasi yang digunakan adalah siswa kelas X SMAN 2 Cikarang Pusat yang berjumlah 220 siswa. Sampel yang digunakan dalam penelitian ini sebanyak 122 siswa dengan teknik pengambilan sampel yaitu qouta sampling. Data pada penelitian dianalisis dengan menggunakan statistik deskriptif dengan presentase. Hasil penelitian menunjukan tingkat pemahaman siswa kelas $X$ dalam pembelajaran daring pendidikan jasmani di SMAN 2 Cikarang Pusat secara keseluruhan berada pada kategori "Cukup Baik" dengan jumlah 51 siswa dan presentase sebesar $(42 \%)$.
\end{abstract}

Kata Kunci: tingkat pemahaman; daring; pendidikan jasmani

\begin{abstract}
This research is motivated by the absence of learning theory in class that is devoted to physical education, and the learning time is very minimal so that students find it difficult to understand physical education learning. This study aims to determine the level of understanding of class $X$ students in learning physical education online at SMAN 2 Cikarang Pusat. This research is a descriptive quantitative research, the method used is a survey. The data collection technique was in the form of a questionnaire using a multiple choice test. The population used was class X SMAN 2 Cikarang Pusat, totaling 220 students. The sample used in this study were 122 students with a sampling technique that is qouta sampling. The data in the study were analyzed using descriptive statistics with percentages. The results showed the level of understanding of class $X$ students in learning physical education online at SMAN 2 Cikarang Pusat as a whole was in the "Good Enough" category with a total of 51 students and a percentage of (42\%).
\end{abstract}

Keywords: comprehension level; online; physical education

Dipublikasikan Oleh :

UPT Publikasi dan Pengelolaan Jurnal

Universitas Islam Kalimantan Muhammad Arsyad Al-Banjari Banjarmasin 


\section{PENDAHULUAN}

Pembelajaran adalah suatu proses kegiatan yang sistematis bersifat interaktif dan komunikatif antara pendidik dengan peserta didik, sumber belajar dan lingkungan untuk menciptakan suatu kondisi yang memungkinkan terjadinya tindakan belajar peserta didik, baik di kelas maupun di luar kelas, dihadiri guru secara fisik atau tidak, untuk menguasai kompetensi yang telah ditentukan oleh Arifin, (2015:17).

Bentuk pembelajaran yang dapat dijadikan solusi dalam masa pandemi Covid-19 adalah pembelajaran daring. Pembelajaran daring merupakan pembelajaran yang menggunakan jaringan internet dengan aksesibilitas, konektivitas, dan kemampuan untuk memunculkan berbagai jenis interaksi pembelajaran yang telah dikemukakan oleh Setiawan, (2019:216). Dari pendapapat peneliti dapat ditarik kesimpulan bahwa pembelajaran daring adalah pembelajaran jarak jauh yang memanfaatkan suatu teknologi dalam proses pembelajaran, agar pembelajaran tetap efektif demi tercapainya tujuan pembelajaran di masa pandemi seperti ini.

Kegiatan pembelajaran pendidikan jasmani agar berlangsung secara efektif dan peserta didik dapat memahaminya, strategi pembelajaran yang digunakan adalah dapat ditunjang oleh pemanfaatan media pembelajaran yang telah ditentukan oleh Jatmika, (2010:91). Beragam pilihan media pembelajaran yang bisa dimanfaatkan guru pendidikan jasmani untuk kepentingan penyampaian materi kepada peserta didik. Pembelajaran daring merupakan salah satu media pembelajaran yang dapat membantu guru pendidikan jasmani dalam proses pembelajaran pendidikan jasmani.

Pemahaman adalah suatu kemampuan seseorang untuk mengerti atau memahami sesuatu setelah sesuatu itu dipahami dan diingat yang telah ditentukan oleh Ulinnuha, (2017:86). Pemahaman belajar adalah tingkat kemampuan yang mengharapkan seseorang mampu memahami arti atau konsep dan situasi fakta yang diketahuinya, dalam hal ini peserta didik tidak hanya hafal secara verbalitas, tetapi memahami konsep dari masalah atau fakta yang ditanyakan, maka operasionalnya dapat membedakan, mengubah, mempersiapkan, menjelaskan, mendemonstrasikan, memberi contoh, memperkirakan, menentukan, dan mengambil keputusan yang telah ditentukan oleh Walangadi \& Pratama, (2020:202). Dengan kata lain, pemahaman adalah mengerti atau dapat menjelaskan apa yang telah diingat dan telah dipelajari dari sesuatu yang telah didapatkan. Dengan banyaknya manfaat akan pemahaman dalam pembelajaran pendidikan jasmani, siswa akan lebih cepat bisa melakukan pembelajaran setelah memahami apa yang akan di pelajari.

Pada pelaksanaan observasi melalui wawancara di rumah salah satu guru pendidikan jasmani SMAN 2 Cikarang Pusat, guru pendidikan jasmani pun menjelaskan masih banyak siswa kelas $\mathrm{X}$ yang belum menunjukan hasil maksimal dalam pembelajaran dan masih banyak siswa kelas $\mathrm{X}$ yang belum memahami dalam pembelajaran pendidikan jasmani. Hal itu dapat dilihat dari penjelasan guru pendidikan jasmani tersebut ketika peneliti hendak mewawancarai guru tersebut.

Permasalahan diatas menginspirasi penulis untuk melakukan penelitian terhadap tingkat pemahaman siswa kelas X dalam pembelajaran daring pendidikan jasmani di SMAN 2 Cikarang Pusat. Hal tersebut bertujuan sebagai bahan evaluasi bagi siswa untuk dapat meningkatkan pemahaman siswa dalam pembelajaran pendidikan jasmani secara daring. Hal itu dapat dibuktikan melalui penelitian terdahulu yang dilakukan oleh Dinata, (2019) degan judul "Tingkat Pemahaman Guru Penjas Terhadap Penerapan E-Learning Dalam Proses Pembelajaran Sekolah Menengah Pertama". Penelitian ini menggunakan pendekatan deskriptif kuantitatif dengan subjek penelitian adalah guru. Adapun teknik pengumpulan data yang digunakan yaitu observasi dan lembar kuesioner. Analisis data dengan menggunakan skala likert dengan menggunakan lima skala. Hasil penelitian menunjukkan bahwa diperoleh skor $69 \%$ dengan kategori cukup baik. Hal ini dikarenakan pelaksanaan e-learning belum digunakan secara maksimal, hanya digunakan beberapa kali saja dalam seminggu oleh guru. Sedangkan, dalam penelitian ini penulis mengganti sampel untuk mengetahui tingkat pemahaman siswa dalam pembelajaran pendidikan jasmani dan memperbaharui instrument yang digunakan dengan menyesuaikan rancangan pelaksanaan pembelajaran pendidikan jasmani yang digunakan guru di SMAN 2 Cikarang Pusat.

Seorang guru penjas dalam melakukan pembelajaran daring pendidikan jasmani sebaiknya harus dapat melihat terlebih dahulu seberapa paham semua siswa dalam pembelajaran daring pendidikan jasmani, yang meliputi pemahaman mengenai pendidikan jasmani secara umum, sarana dan prasarana yang digunakan, teknik dasar, dan peraturan dalam pembelajaran pendidikan jasmani. Setelah melakukan proses tersebut dapat

Dipublikasikan Oleh :

UPT Publikasi dan Pengelolaan Jurnal

Universitas Islam Kalimantan Muhammad Arsyad Al-Banjari Banjarmasin 
dilakukan dengan baik dan yang paling penting tidak terjadi kecelakaan. Oleh karena itu maka mengetahui tingkat pemahaman dan keterampilan siswa sangat penting sebelum melakukan proses pembelajaran.

\section{METODE}

Penelitian ini menggunakan metode deskriptif dengan pendekatan kuantitatif melalui penggunaan instrumen survey untuk mengetahui tingkat pemahaman siswa kelas $\mathrm{X}$ dalam pembelajaran daring pendidikan jasmani.

Sebelum kuisioner digunakan, maka diperlukan uji instrumen berupa uji validasi konstruksi (expert judgement) yang telah diujikan oleh Dosen Pendidikan Jasmani Dan Rekreasi Universitas Singaperbangsa Irfan Zinat Achmad, S.Pd., M.Pd. lalu uji validitas untuk mengukur ketepatan disetiap butir soal, digunakan teknik person product momen dengan taraf signifikansi $5 \%$. Butir soal dikatakan valid apabila $\mathrm{r}_{\text {hitung }}>\mathrm{r}_{\text {tabel }}$, untuk nilai $\mathrm{r}_{\text {tabel }}$ dengan responden 10 orang adalah sebesar 0,632. Setelah dilakukan perhitungan dapat diketahui ada 11 butir soal yang menunjukan tidak valid karena hasil $r$ hitung kurang dari $r$ tabel $(0,632)$. Butir soal yang tidak valid yaitu soal nomor 13 dengan $r$ tabel $(0,359)$, soal nomor 15 dengan $r$ tabel $(0,045)$, soal nomor 19 dengan $r$ tabel $(0,479)$, soal nomor 21 dengan $r$ tabel $(0,235)$, soal nomor 22 dengan $r$ tabel $(0,157)$, soal nomor 23 dengan $\mathrm{r}$ tabel $(0,549)$, soal nomor 28 dengan $\mathrm{r}$ tabel $(0,440)$, soal nomor 29 dengan $\mathrm{r}$ tabel $(0,353)$, soal nomor 37 dengan $r$ tabel $(0,180)$, soal nomot 38 dengan $r$ tabel $(0,180)$, dan soal nomor 40 dengan $r$ tabel $(0,440)$. Selanjutnya ke sebelas soal tersebut tidak digunakan pada penelitian karena butir soal yang valid sudah mewakili untuk digunakan penelitian yang sesungguhnya, jadi soal pilihan ganda yang digunakan untuk penelitian menjadi 29 butir. Jadi peneliti hanya memakai 29 butir soal dari total 40 butir soal, dan dilakukan uji reabilitas dengan menggunakan rumus alpha cronbach dengan taraf signifikansi 5\%, suatu instrumen dikatakan reliable jika $\mathrm{r}_{11}>$ $r_{\text {tabel }}$, hasil uji reabilitas diperoleh nilai $r_{11}=0,761>r_{\text {tabel }}=0,632$ dengan demikian menunjukan angket yang diuji cobakan reliable dan dapat digunakan untuk pengumpulan data penelitian.

Adapun Desain dalam penelitian yang dilakukan dalam penelitian ini menggunakan langkah langkah penelitian kuantitatif deskriptif terdiri dari: (a) Mengidentifikasi adanya permasalahan yang signifikan untuk dipecahkan melalui metode deskriptif, (b) Membatasi dan merumuskan permasalahan secara jelas, (c) Menentukan tujuan dan manfaat penelitian, (d) Melakukan studi pustaka yang berkaitan dengan permasalahan, (e) Menentukan kerangka berpikir, dan pertanyaan penelitian dan atau hipotesis penelitian, (f) Mendesain metode penelitian yang hendak digunakan termasuk dalam hal ini menentukan populasi, sampel, teknik sampling, menentukan instrumen, mengumpulkan data, dan menganalisis data, (g) Mengumpulkan, mengorganisasikan, dan menganalisis data dengan menggunakan teknik statistika yang relevan, dan (h) Membuat laporan penelitian.

Populasi dalam penelitian ini adalah siswa kelas X SMAN 2 Cikarang Pusat dengan jumlah 2 program keahlian yaitu MIPA dan IPS, 6 Kelas dan 220 siswa. Dan penentuan jumlah sampel menurut Sugiyono, (2013:87) dengan batas toleransi kesalahan 1\%, 5\%, dan 10\%. Peneliti mengambil sampel dengan batas toleransi kesalahan $10 \%$, yang didasari dari hasil perhitugan pada subjek dengan besar populasi 251 maka sampel penelitian sebesar 130 responden. Dalam perhitungan 39tatistic menggunakan bantuan aplikasi microsoft excel 2013. Selanjutnya data disajikan dalam bentuk tabel frekuensi dan kemudian dilakukan pengkategorian serta menyajikan data dalam bentuk histogram. Dalam pengkategorian skor mengunakan lima kategori yaitu, sangat baik, baik, cukup baik, kurang baik, dan sangat tidak baik yang telah di kemukakan oleh Achmad, (2013:8) :

Tabel 1. Norma Pengkategorian

\begin{tabular}{cc}
\hline Interval & Kategori \\
\hline $\mathrm{M}+1,5 \mathrm{SD} \leq \mathrm{X}$ & Sangat baik \\
$\mathrm{M}+0,5 \mathrm{SD} \leq \mathrm{X}<\mathrm{M}+1,5 \mathrm{SD}$ & Baik \\
$\mathrm{M}-0,5 \mathrm{SD} \leq \mathrm{X}<\mathrm{M}+0,5 \mathrm{SD}$ & Cukup baik \\
$\mathrm{M}-1,5 \mathrm{SD} \leq \mathrm{X}<\mathrm{M}-0,5 \mathrm{SD}$ & Kurang baik \\
$\mathrm{X}<\mathrm{M}-1,5 \mathrm{SD}$ & Sangat tidak baik \\
\hline
\end{tabular}

\section{HASIL DAN PEMBAHASAN}

Penelitian ini merupakan penelitian deskriptif, sehingga keadaan objek akan digambarkan sesuai dengan keadaan sesungguhnya yang diperoleh oleh peneliti. Sebelum penelitian ini dilakukan peneliti telah meminta izin untuk melakukan penelitian pada siswa kelas X SMAN 2 Cikarang Pusat dan kepada bagian kesiswaan dan bagian staff di sekolah tersebut, dikarenakan pada saat itu kepala sekolah SMAN 2 Cikarang Pusat sedang tidak ada ditempat. Dan mendapatkan izin pada tanggal 29 Oktober 2020 Untuk menyebar angket atau kuisioner berupa soal pilihan ganda, karena dalam keadaan wabah Covid -19 jadi pengambilan data ini dilakukan malalui google formulir. Angket yang digunakan diisi oleh responden sebanyak 122 siswa dari total populasi 220 siswa.

Dipublikasikan Oleh :

UPT Publikasi dan Pengelolaan Jurnal

Universitas Islam Kalimantan Muhammad Arsyad Al-Banjari Banjarmasin 
Selanjutnya responden mengisi angket atau kuisioner berupa soal pilihan ganda sebanyak 29 soal, dengan 5 pilihan jawaban setiap soalnya. Tingkat pemahaman siswa kelas $\mathrm{X}$ dalam pembelajaran daring pendidikan jasmani di SMAN 2 Cikarang Pusat meliputi tujuh faktor yaitu, tingkat pemahaman siswa mengenai permainan dan olahraga, tingkat pemahaman siswa mengenai aktivitas pengembangan diri, tingkat pemahaman siswa mengenai aktivitas senam, tingkat pemahaman siswa mengenai aktivitas ritmik, tingkat pemahaman siswa mengenai aktivitas akuatik, tingkat pemahaman siswa mengenai pendidikan luar kelas, dan tingkat pemahaman siswa mengenai kesehatan. Dikarenakan dalam faktor tingkat pemahaman siswa mengenai aktivitas ritmik tidak ada butir soal yang valid, maka faktor tersebut ditiadakan. Setelah data penelitian terkumpul dilakukan analisis dengan menggunakan teknik anaisis deskriptif kuantitatif dengan presentase menggunakan bantuan Microsoft excel 2013 for windows. Dari hasil penelitian yang diperoleh, tingkat pemahaman aktivitas renang siswa kelas $\mathrm{X}$ di kategorikan menjadi 5 kategori yaitu kategori sangat baik, baik, cukup baik, kurang baik dan sangat tidak baik. Sehingga statistik deskriptif mengenai tingkat pemahaman aktivitas renang siswa kelas X dapat dilihat pada table berikut :

Tabel 2. Hasil Statistik Deskriptif Penelitian

\begin{tabular}{cccccccc}
\hline Keterangan & Keseluruhan & $\begin{array}{c}\text { Pemainan } \\
\text { dan } \\
\text { Olahraga }\end{array}$ & $\begin{array}{c}\text { Aktifitas } \\
\text { Pengembangan } \\
\text { Diri }\end{array}$ & $\begin{array}{c}\text { Aktivitas } \\
\text { Senam }\end{array}$ & $\begin{array}{c}\text { Aktivitas } \\
\text { Akuatik }\end{array}$ & $\begin{array}{c}\text { Pendidikan } \\
\text { Luar Kelas }\end{array}$ & Kesehatan \\
\hline $\begin{array}{l}\text { Mean } \\
\text { Standar } \\
\text { Deviasi }\end{array}$ & 23,28 & 11,89 & 1,80 & 1,61 & 2,52 & 1,87 & 3,70 \\
Median & 24 & 2,09 & 0,46 & 0,55 & 1,19 & 0,38 & 0,70 \\
Range & 16 & 12 & 2 & 2 & 2,50 & 2 & 4 \\
Minimum & 13 & 9 & 2 & 2 & 4 & 2 & 3 \\
Maximum & 29 & 15 & 2 & 0 & 2 & 4 & 2 \\
\hline
\end{tabular}

Hasil analisis data statistik penelitian secara keseluruhan memperoleh nilai mean sebesar 23,28, standar deviasi sebesar 3,39, median sebesar 24, range sebesar 16, nilai minimum sebesar 13, dan nilai maksimum sebesar 29. Kemudian hasil data statistik secara ideal dimasukan kedalam table distribusi frekuensi, maka data tingkat pemahaman siswa kelas X dalam pembelajaran daring pendidikan jasmani di SMAN 2 Cikarang Pusat :

Tabel 3. Tingkat Pemahaman Siswa Kelas X Dalam Pembelajaran Daring Pendidikan Jasmani Di SMAN 2 Cikarang Pusat

\begin{tabular}{ccccccc}
\hline No & & Interval & & Kategori & Frekuensi & $\%$ \\
\hline 1 & & $\mathrm{x}>$ & 28,46 & Sangat Baik & 4 & $3 \%$ \\
2 & 25,07 & $<\mathrm{x}<$ & 28,46 & Baik & 31 & $25 \%$ \\
3 & 21,68 & $<\mathrm{x}<$ & 25,07 & Cukup Baik & 51 & $42 \%$ \\
4 & 18,30 & $<\mathrm{x}<$ & 21,68 & Kurang Baik & 25 & $20 \%$ \\
5 & & $\mathrm{x}<$ & 18,30 & Sangat Tidak Baik & 11 & $9 \%$ \\
\hline & & & Jumlah & & 122 & $100 \%$ \\
\hline
\end{tabular}

Berdasarkan tabel tersebut dapat dijelaskan bahwa secara keseluruhan tingkat pemahaman siswa kelas $\mathrm{X}$ dalam pembelajaran daring pendidikan jasmani di SMAN 2 Cikarang Pusat, secara rinci terdapat 4 siswa (3\%) dalam kategori "Sangat Baik", 31 siswa (25\%) dalam kategori "Baik", 51 siswa (42\%) dalam kategori "Cukup Baik", 25 siswa (20\%) dalam kategori "Kurang Baik", dan 11 siswa (9\%) dalam kategori "Sangat Tidak Baik". Frekuensi terbanyak terdapat pada kategori "Cukup Baik", sehingga dapat disimpulkan tingkat pemahaman siswa kelas X dalam pembelajaran daring pendidikan jasmani di SMAN 2 Cikarang Pusat berkategori "Cukup Baik”. Apabila digambarkan dalam bentuk diagram sebagai berikut :

Dipublikasikan Oleh :

UPT Publikasi dan Pengelolaan Jurnal

Universitas Islam Kalimantan Muhammad Arsyad Al-Banjari Banjarmasin 


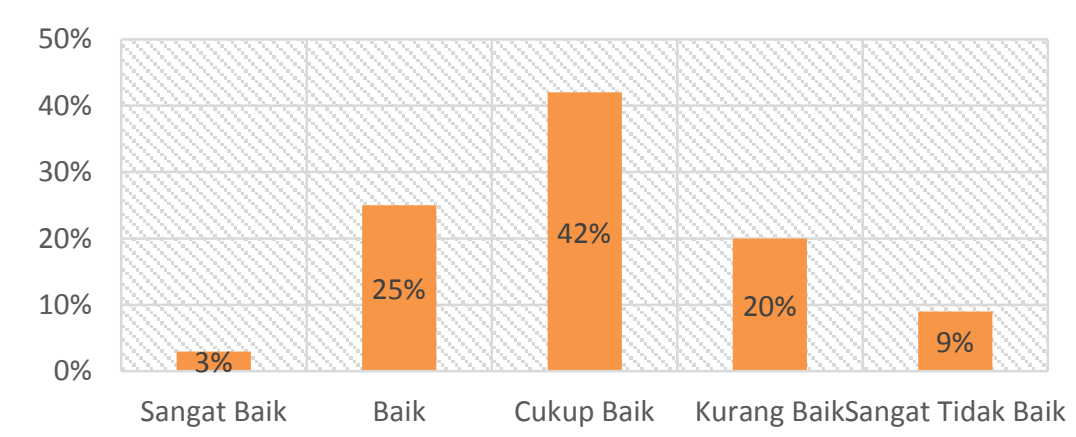

\section{Gambar 1. Tingkat Pemahaman Siswa Kelas X Dalam Pembelajaran Daring Pendidikan Jasmani Di SMAN 2 Cikarang Utara Secara Keseluruhan}

\section{Faktor Permainan Dan Olahraga}

Dalam instrumen penelitian ini terdapat 8 indikator yaitu sepakbola, bolavoli, bulutangkis, tenis meja, lari jarak pendek, tolak peluru, lompat jauh, dan lompat tinggi. Masing-masing indikator dijabarkan melalui beberapa butir pertanyaan, sepakbola 3 butir pertanyaan, bolavoli 2 butir pertanyaan, bulutangkis 3 butir pertanyaan, tenis meja 1 butir pertanyaan, lari jarak pendek 1 butir pertanyaan, tolak peluru 2 butir pertanyaan, lompat jauh 1 butir pertanyaan, dan lompat tinggi 1 butir pertanyaan. Tetapi dalam lompat jauh terdapat 1 butir soal dinyatakan tidak valid, jadi dalam lompat jauh hanya menggunakan 1 butir pertanyaan. Dari semua soal lainnya dinyatakan valid, sehingga layak digunakan sebagai instrumen penelitian.

Berdasarkan hasil penelitian dari faktor permainan dan olahraga diperoleh mean sebesar 11,89, standar deviasi sebesar 2,09, range sebesar 9, median sebesar 12, nilai minimum 6 dan nilai maximum 15. Setelah diketahui dapat dimasukan kedalam tabel distribusi frekuensi sebagai berikut:

Tabel 4. Faktor Permainan Dan Olahraga

\begin{tabular}{ccccccc}
\hline No & & Interval & & Kategori & Frekuensi & $\%$ \\
\hline 1 & & $\mathrm{x}>$ & 15,03 & Sangat Baik & 0 & $0 \%$ \\
2 & 12,93 & $<\mathrm{x}<$ & 15,03 & Baik & 59 & $48 \%$ \\
3 & 10,84 & $<\mathrm{x}<$ & 12,93 & Cukup Baik & 34 & $28 \%$ \\
4 & 8,74 & $<\mathrm{x}<$ & 10,84 & Kurang Baik & 18 & $15 \%$ \\
5 & & $\mathrm{x}<$ & 8,74 & Sangat Tidak Baik & 11 & $9 \%$ \\
\hline & & & & 122 & $100 \%$ \\
\hline
\end{tabular}

Berdasarkan tabel tersebut dapat dijelaskan tingkat pemahaman siswa kelas X dalam pembelajaran daring pendidikan jasmani di SMAN 2 Cikarang Pusat berdasarkan faktor permainan dan olahraga, secara rinci terdapat 0 siswa $(0 \%)$ dalam kategori "Sangat Baik", 59 siswa (48\%) dalam kategori "Baik", 34 siswa (28\%) dalam kategori "Cukup Baik", 18 siswa (15\%) dalam kategori "Kurang Baik", 11 siswa (9\%) dalam kategori "Sangat Tidak Baik". Frekuensi terbanyak terdapat pada kategori "Baik", sehingga dapat disimpulkan tingkat pemahaman siswa kelas $\mathrm{X}$ dalam pembelajaran daring pendidikan jasmani di SMAN 2 Cikarang Pusat berdasarkan faktor permainan dan olahraga berkategori "Baik". Apabila digambarkan dalam bentuk diagram batang diperoleh sebagai berikut :

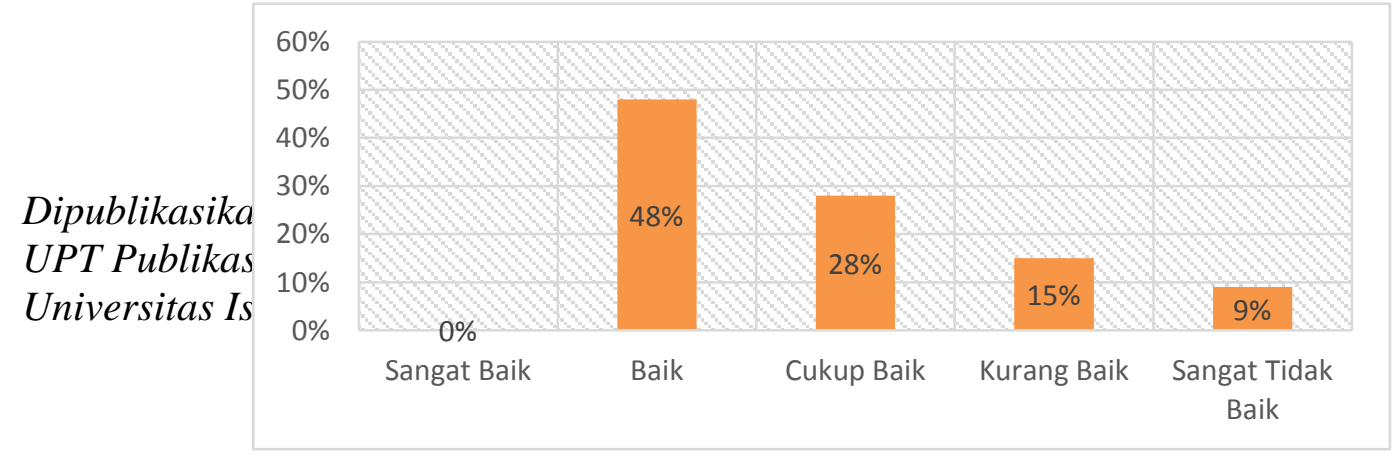




\section{Gambar 2. Diagram Batang Faktor Permainan Dan Olahraga \\ Faktor Aktivitas Pengembangan Diri}

Dalam instrumen penelitian ini terdapat 1 indikator yaitu kebugaran jasmani. Indikator dijabarkan melalui beberapa butir pertanyaan, kebugaran jasmani meliputi 3 butir pertanyaan. Tetapi dalam kebugaran jasmani terdapat 1 butir soal dinyatakan tidak valid, jadi dalam kebugaran jasmani hanya menggunakan 2 butir pertanyaan. Dari semua soal lainnya dinyatakan valid, sehingga layak digunakan sebagai instrumen penelitian.

Berdasarkan hasil penelitian dari faktor aktivitas pengembangan diri dengan indikator kebugaran jasmani diperoleh mean sebesar 1,80, standar deviasi sebesar 0,46, range sebesar 2, median sebesar 2, nilai minimum 0 dan nilai maximum 2. Setelah diketahui dapat dimasukan kedalam tabel distribusi frekuensi sebagai berikut:

Tabel 5. Faktor Aktivitas Pengembangan Diri

\begin{tabular}{ccccccc}
\hline No & & Interval & & Kategori & Frekuensi & $\%$ \\
\hline 1 & & $\mathrm{x}>$ & 2,49 & Sangat Baik & 0 & $0 \%$ \\
2 & 2,03 & $<\mathrm{x}<$ & 2,49 & Baik & 0 & $0 \%$ \\
3 & 1,56 & $<\mathrm{x}<$ & 2,03 & Cukup Baik & 100 & $82 \%$ \\
4 & 1,10 & $<\mathrm{x}<$ & 1,56 & Kurang Baik & 0 & $0 \%$ \\
5 & & $\mathrm{x}<$ & 1,10 & Sangat Tidak Baik & 22 & $18 \%$ \\
\hline \multicolumn{7}{c}{ Jumlah } \\
\hline
\end{tabular}

Berdasarkan tabel tersebut dapat dijelaskan tingkat pemahaman siswa kelas $\mathrm{X}$ dalam pembelajaran daring pendidikan jasmani di SMAN 2 Cikarang Pusat berdasarkan faktor aktivitas pengembangan diri dengan indikator kebugaran jasmani, secara rinci terdapat 0 siswa $(0 \%)$ dalam kategori "Sangat Baik", 0 siswa $(0 \%)$ dalam kategori "Baik", 100 siswa (82\%) dalam kategori "Cukup Baik", 0 siswa (0\%) dalam kategori "Kurang Baik", 22 siswa (18\%) dalam kategori "Sangat Tidak Baik". Frekuensi terbanyak terdapat pada kategori "Cukup Baik", sehingga dapat disimpulkan tingkat pemahaman siswa kelas X dalam pembelajaran daring pendidikan jasmani di SMAN 2 Cikarang Pusat berdasarkan faktor aktivitas pengembangan diri dengan indikator kebugaran jasmani berkategori "Cukup Baik". Apabila digambarkan dalam bentuk diagram batang diperoleh sebagai berikut :

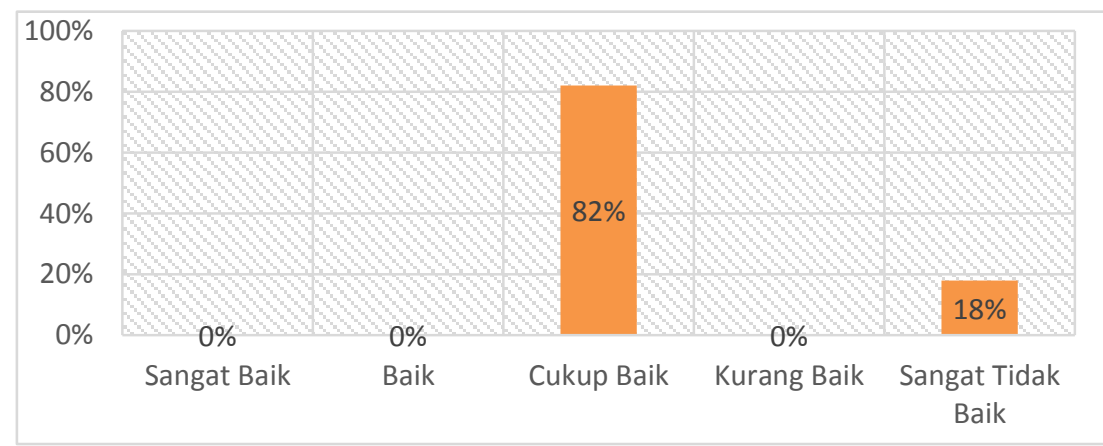

Gambar 3. Diagram Batang Faktor Aktivitas Pengembangan Diri

\section{Faktor Aktivitas Senam}

Dalam instrumen penelitian ini terdapat 1 indikator yaitu senam lantai. Indikator dijabarkan melalui beberapa butir pertanyaan, senam lantai meliputi 3 butir pertanyaan. Tetapi dalam kebugaran jasmani terdapat 1 butir soal dinyatakan tidak valid, jadi dalam kebugaran jasmani hanya menggunakan 2 butir pertanyaan. Dari semua soal lainnya dinyatakan valid, sehingga layak digunakan sebagai instrumen penelitian.

Berdasarkan hasil penelitian dari faktor aktivitas senam dengan indikator senam lantai diperoleh mean sebesar 1,61, standar deviasi sebesar 0,55 , range sebesar 2, median sebesar 2, nilai minimum 0 dan nilai maximum 2. Setelah diketahui dapat dimasukan kedalam tabel distribusi frekuensi sebagai berikut:

Tabel 6. Faktor Aktivitas Senam

\begin{tabular}{ccccccc}
\hline No & & Interval & & Kategori & Frekuensi & $\%$ \\
\hline 1 & & $\mathrm{x}>$ & 2,44 & Sangat Baik & 0 & $0 \%$ \\
2 & 1,88 & $<\mathrm{x}<$ & 2,44 & Baik & 78 & $64 \%$ \\
3 & 1,33 & $<\mathrm{x}<$ & 1,88 & Cukup Baik & 0 & $0 \%$ \\
4 & 0,78 & $<\mathrm{x}<$ & 1,33 & Kurang Baik & 40 & $33 \%$ \\
\hline
\end{tabular}

Dipublikasikan Oleh :

UPT Publikasi dan Pengelolaan Jurnal

Universitas Islam Kalimantan Muhammad Arsyad Al-Banjari Banjarmasin 


\begin{tabular}{cccccc}
\hline 5 & $\mathrm{x}<$ & 0,78 & Sangat Tidak Baik & 4 & $3 \%$ \\
\hline & Jumlah & & 122 & $100 \%$ \\
\hline
\end{tabular}

Berdasarkan tabel tersebut dapat dijelaskan tingkat pemahaman siswa kelas X dalam pembelajaran daring pendidikan jasmani di SMAN 2 Cikarang Pusat berdasarkan faktor aktivitas senam dengan indikator senam lantai, secara rinci terdapat 0 siswa $(0 \%)$ dalam kategori "Sangat Baik", 78 siswa (64\%) dalam kategori "Baik", 0 siswa (0\%) dalam kategori "Cukup Baik", 40 siswa (33\%) dalam kategori "Kurang Baik", 4 siswa (3\%) dalam kategori "Sangat Tidak Baik". Frekuensi terbanyak terdapat pada kategori "Baik", sehingga dapat disimpulkan tingkat pemahaman siswa kelas X dalam pembelajaran daring pendidikan jasmani di SMAN 2 Cikarang Pusat berdasarkan faktor aktivitas senam dengan indikator senam lantai berkategori "Baik". Apabila digambarkan dalam bentuk diagram batang diperoleh sebagai berikut :

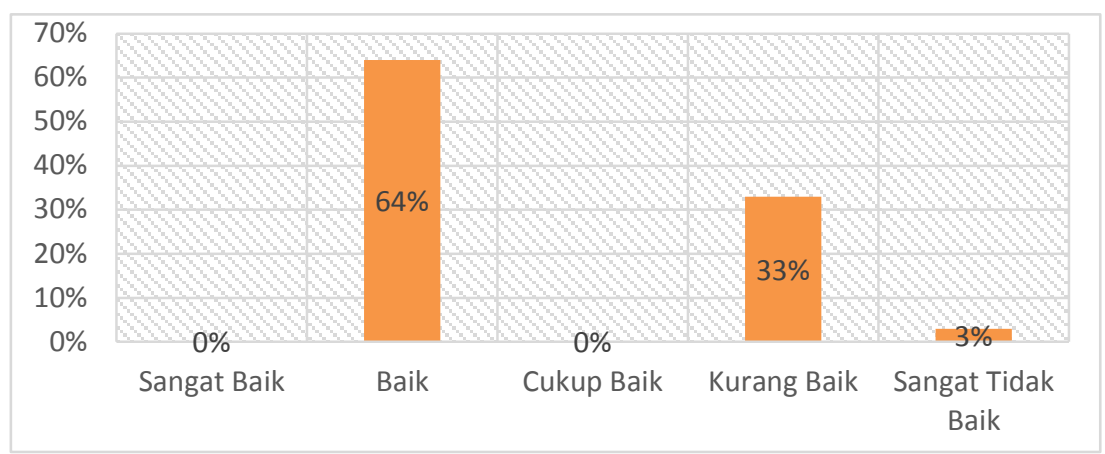

Gambar 4. Diagram Batang Faktor Aktivitas Senam

\section{Faktor Aktivitas Akuatik}

Dalam instrumen penelitian ini terdapat 3 indikator yaitu renang gaya bebas, renang gaya punggung, renang gaya dada. Indikator dijabarkan melalui beberapa butir pertanyaan, renang gaya bebas meliputi 2 butir pertanyaan, renang gaya punggung meliputi 2 butir pertanyaan, dan renang gaya dada meliputi 2 butir pertanyaan. Tetapi dalam aktivitas akuatik terdapat 1 indikator dinyatakan tidak valid yaitu renang gaya dada yang meliputi 2 butir pertanyaan, jadi dalam aktivitas akuatik hanya menggunakan 4 butir pertanyaan. Dari semua soal lainnya dinyatakan valid, sehingga layak digunakan sebagai instrumen penelitian.

Berdasarkan hasil penelitian dari faktor aktivitas akuatik diperoleh mean sebesar 2,52, standar deviasi sebesar 1,19, range sebesar 4, median sebesar 2,50, nilai minimum 0 dan nilai maximum 4 . Setelah diketahui dapat dimasukan kedalam tabel distribusi frekuensi sebagai berikut :

Tabel 7. Faktor Aktivitas Akuatik

\begin{tabular}{|c|c|c|c|c|c|c|}
\hline No & & Interva & & Kategori & Frekuensi & $\%$ \\
\hline 1 & & $x>$ & 4,30 & Sangat Baik & 0 & $0 \%$ \\
\hline 2 & 3,12 & $<\mathrm{x}<$ & 4,30 & Baik & 32 & $26 \%$ \\
\hline 3 & 1,93 & $<x<$ & 3,12 & Cukup Baik & 70 & $57 \%$ \\
\hline 4 & 0,74 & $<\mathrm{x}<$ & 1,93 & Kurang Baik & 11 & $9 \%$ \\
\hline 5 & & $x<$ & 0,74 & Sangat Tidak Baik & 9 & $7 \%$ \\
\hline \multicolumn{5}{|c|}{ Jumlah } & 122 & $100 \%$ \\
\hline
\end{tabular}

Berdasarkan tabel tersebut dapat dijelaskan tingkat pemahaman siswa kelas $\mathrm{X}$ dalam pembelajaran daring pendidikan jasmani di SMAN 2 Cikarang Pusat berdasarkan faktor aktivitas akuatik, secara rinci terdapat 0 siswa (0\%) dalam kategori "Sangat Baik", 32 siswa (26\%) dalam kategori "Baik", 70 siswa (57\%) dalam kategori "Cukup Baik", 11 siswa (9\%) dalam kategori "Kurang Baik", 9 siswa (7\%) dalam kategori "Sangat Tidak Baik". Frekuensi terbanyak terdapat pada kategori "Cukup Baik", sehingga dapat disimpulkan tingkat pemahaman siswa kelas $\mathrm{X}$ dalam pembelajaran daring pendidikan jasmani di SMAN 2 Cikarang Pusat berdasarkan faktor aktivitas akuatik berkategori "Cukup Baik". Apabila digambarkan dalam bentuk diagram batang diperoleh sebagai berikut :

Dipublikasikan Oleh :

UPT Publikasi dan Pengelolaan Jurnal

Universitas Islam Kalimantan Muhammad Arsyad Al-Banjari Banjarmasin 


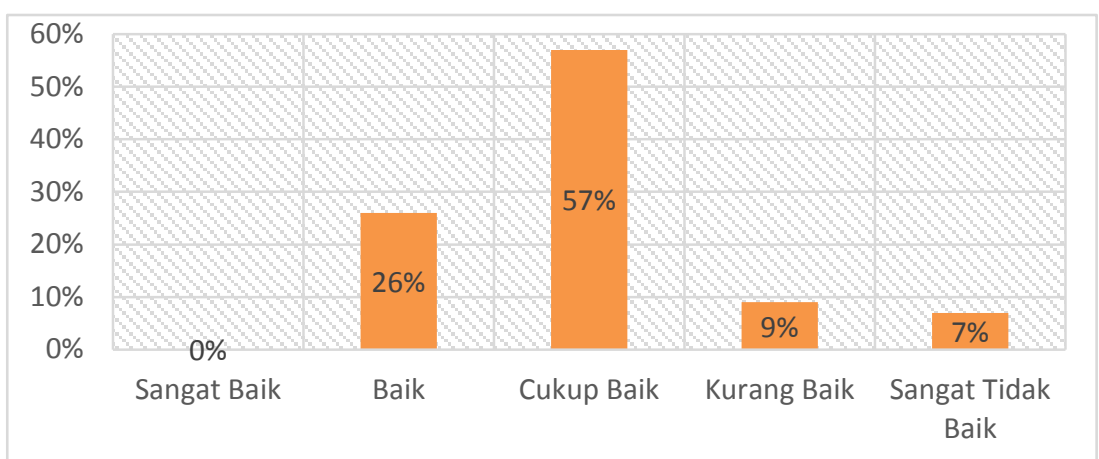

Gambar 5. Diagram Batang Faktor Aktivitas Akuatik

\section{Faktor Pendidikan Luar Kelas}

Dalam instrumen penelitian ini terdapat 1 indikator yaitu kegiatan outbound. Indikator dijabarkan melalui beberapa butir pertanyaan, kegiatan outbound meliputi 2 butir pertanyaan. Dari semua soal dinyatakan valid, sehingga layak digunakan sebagai instrumen penelitian.

Berdasarkan hasil penelitian dari faktor pendidikan luar kelas dengan indikator kegiatan outbound diperoleh mean sebesar 1,87, standar deviasi sebesar 0,38, range sebesar 2, median sebesar 2, nilai minimum 0 dan nilai maximum 2. Setelah diketahui dapat dimasukan kedalam tabel distribusi frekuensi sebagai berikut:

Tabel 8. Faktor Pendidikan Luar Kelas

\begin{tabular}{|c|c|c|c|c|c|c|}
\hline No & & Interval & & Kategori & Frekuensi & $\%$ \\
\hline 1 & & $x>$ & 2,45 & Sangat Baik & 0 & $0 \%$ \\
\hline 2 & 2,06 & $<\mathrm{x}<$ & 2,45 & Baik & 0 & $0 \%$ \\
\hline 3 & 1,68 & $<\mathrm{x}<$ & 2,06 & Cukup Baik & 108 & $89 \%$ \\
\hline 4 & 1,29 & $<x<$ & 1,68 & Kurang Baik & 0 & $0 \%$ \\
\hline 5 & & $x<$ & 1,29 & Sangat Tidak Baik & 14 & $11 \%$ \\
\hline \multicolumn{5}{|c|}{ Jumlah } & 122 & $100 \%$ \\
\hline
\end{tabular}

Berdasarkan tabel tersebut dapat dijelaskan tingkat pemahaman siswa kelas X dalam pembelajaran daring pendidikan jasmani di SMAN 2 Cikarang Pusat berdasarkan faktor pendidikan luar kelas dengan indikator kegiatan outbound, secara rinci terdapat 0 siswa (0\%) dalam kategori "Sangat Baik, 0 siswa (0\%) dalam kategori "Baik", 108 siswa (89\%) dalam kategori "Cukup Baik", 0 siswa (0\%) dalam kategori "Kurang Baik", 14 siswa (11\%) dalam kategori "Sangat Tidak Baik". Frekuensi terbanyak terdapat pada kategori "Cukup Baik", sehingga dapat disimpulkan tingkat pemahaman siswa kelas X dalam pembelajaran daring pendidikan jasmani di SMAN 2 Cikarang Pusat berdasarkan faktor pendidikan luar kelas dengan indikator kegiatan outbound berkategori "Cukup Baik". Apabila digambarkan dalam bentuk diagram batang diperoleh sebagai berikut :

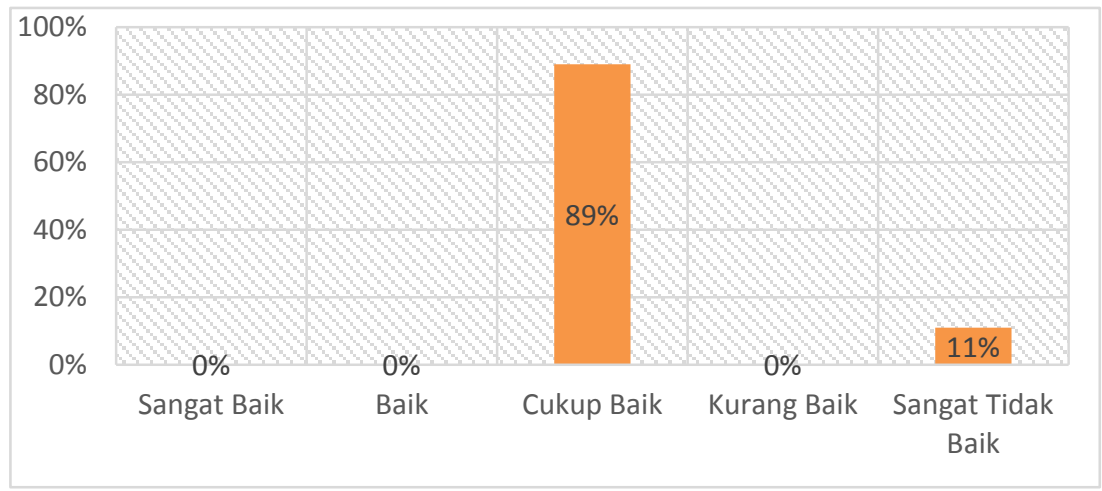

Gambar 6. Diagram Batang Pendidikan Luar Kelas

Faktor Kesehatan

Dipublikasikan Oleh :

UPT Publikasi dan Pengelolaan Jurnal

Universitas Islam Kalimantan Muhammad Arsyad Al-Banjari Banjarmasin 
Dalam instrumen penelitian ini terdapat 2 indikator yaitu pergaulan sehat dan narkoba. Indikator dijabarkan melalui beberapa butir pertanyaan, pergaulan sehat meliputi 2 butir pertanyaan, narkoba meliputi 2 butir pertanyaan. Jadi dalam faktor kesehatan menggunakan 4 butir pertanyaan. Dari semua soal dinyatakan valid, sehingga layak digunakan sebagai instrumen penelitian.

Berdasarkan hasil penelitian dari faktor kesehatan diperoleh mean sebesar 3,70, standar deviasi sebesar 0,70 , range sebesar 3, median sebesar 2,50, nilai minimum 1 dan nilai maximum 4 . Setelah diketahui dapat dimasukan kedalam tabel distribusi frekuensi sebagai berikut :

Tabel 9. Faktor Kesehatan

\begin{tabular}{|c|c|c|c|c|c|c|}
\hline No & & Interval & & Kategori & Frekuensi & $\%$ \\
\hline 1 & & $\overline{x>}$ & 4,75 & Sangat Baik & 0 & $0 \%$ \\
\hline 2 & 4,05 & $<\mathrm{x}<$ & 4,75 & Baik & 0 & $0 \%$ \\
\hline 3 & 3,35 & $<\mathrm{x}<$ & 4,05 & Cukup Baik & 99 & $81 \%$ \\
\hline 4 & 2,64 & $<\mathrm{x}<$ & 3,35 & Kurang Baik & 12 & $10 \%$ \\
\hline 5 & & $x<$ & 2,64 & Sangat Tidak Baik & 11 & $9 \%$ \\
\hline \multicolumn{5}{|c|}{ Jumlah } & 122 & $100 \%$ \\
\hline
\end{tabular}

Berdasarkan tabel tersebut dapat dijelaskan tingkat pemahaman siswa kelas $\mathrm{X}$ dalam pembelajaran daring pendidikan jasmani di SMAN 2 Cikarang Pusat berdasarkan faktor kesehatan, secara rinci terdapat 0 siswa (0\%) dalam kategori "Sangat Baik", 0 siswa (0\%) dalam kategori "Baik", 99 siswa (81\%) dalam kategori "Cukup Baik", 12 siswa (10\%) dalam kategori "Kurang Baik", 11 siswa (9\%) dalam kategori "Sangat Tidak Baik". Frekuensi terbanyak terdapat pada kategori "Cukup Baik", sehingga dapat disimpulkan tingkat pemahaman siswa kelas $\mathrm{X}$ dalam pembelajaran daring pendidikan jasmani di SMAN 2 Cikarang Pusat berdasarkan faktor kesehatan berkategori "Cukup Baik". Apabila digambarkan dalam bentuk :

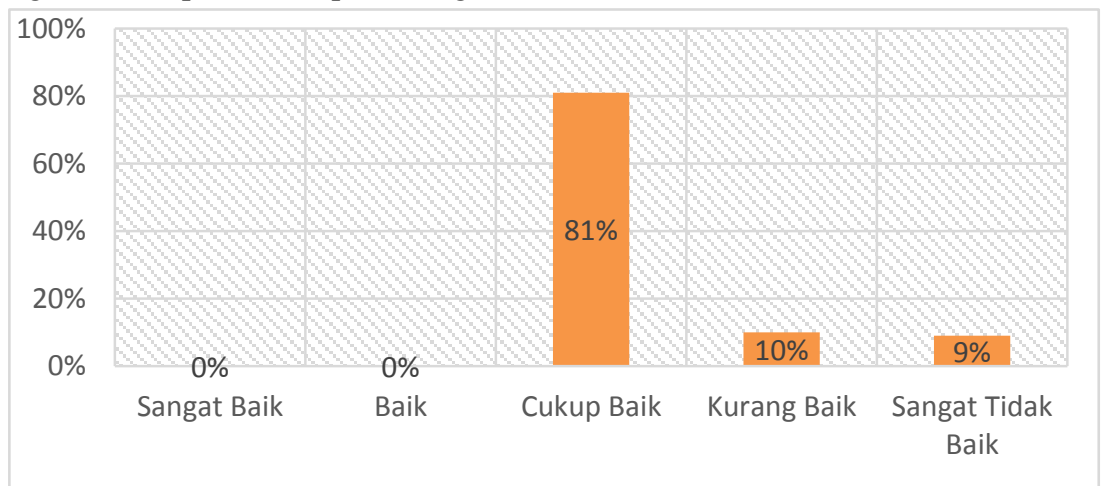

Gambar 7. Diagram Batang Faktor Kesehatan

\section{PENUTUP}

Berdasarkan data yang diperoleh dapat diketahui tingkat pemahaman siswa kelas X dalam pembelajaran daring pendidikan jasmani di SMAN 2 Cikarang Pusat berada pada kategori "Sangat Baik" sebesar 3\% (4 Siswa), kategori "Baik" sebesar 25\% (31 Siswa), kategori "Cukup Baik" sebesar 42\% (51 Siswa), kategori "Kurang Baik" sebesar 20\% (25 Siswa), dan kategori "Sangat Tidak Baik" sebesar 9\% (11 Siswa), Sedangkan berdasarkan nilai rata-rata yaitu 23,38 dari jumlah 29 butir soal. Jadi dapat disimpulkan bahwa secara keseluruhan tingkat pemahaman siswa kelas $\mathrm{X}$ dalam pembelajaran daring pendidikan jasmani di SMAN 2 Cikarang Pusat berada di kategori "Cukup Baik" dengan jumlah 51 siswa dengan presentase 42\%. Berdasarkan penelitian tersebut terdapat saran yang akan disampaikan oleh peneliti yaitu :

1. Peningkatan kualitas pembelajaran pendidikan jasmani ditingkatkan, peningkatan tersebut dapat berupa pembuatan model pembelajaran dan praktik secara langsung agar hasil yang diperoleh dapat maksimal, sehingga tingkat pemahaman siswa tentang pembelajaran pendidikan jasmani meningkat.

2. Perlu adanya penambahan sarana dan prasarana yang mendukung sebagai media pembelajaran, baik yang asli maupun modifikasi sehingga dapat digunakan secara maksimal dalam pembelajaran.

3. Disarankan kepada guru PJOK untuk memberikan materi dikelas sebelum anak melakukan praktek khususnya pada pembelajaran pendidikan jasmani. Sehingga anak dapat memahami dengan baik mengenai gerakan-gerakan yang akan dipraktekan.

Dipublikasikan Oleh :

UPT Publikasi dan Pengelolaan Jurnal

Universitas Islam Kalimantan Muhammad Arsyad Al-Banjari Banjarmasin 
4. Pemanfaatan waktu yang efektif dalam pembelajaran PJOK, sehinga pemahaman teori maupun praktik tentang pendidikan jasmani dapat meningkat dan maksimal.

5. Pemberian motivasi pada setiap pertemuan sehingga meningkatkan minat dan dorongan siswa agar lebih mudah menerima pembelajaran dan dapat menciptakan proses pembelajaran yang kondusif sehingga mampu memberikan hasil yang maksimal.

\section{REFERENSI}

Achmad, I. Z., \& R, A. K. Y. (2013). Persepsi Mahasiswa Pjkr Pada Matakuliah Pembelajaran Permainan Bola Voli Di Universitas Singaperbangsa Karawang. Journal of Chemical Information and Modeling, 53(9), 1689-1699.

Arifin, Z. (2015). Evaluasi Pembelajaran Penulis. In Direktorat Jenderal Pendidikan Islam Kementerian Agama $R I$.

Arikunto, S. (2014). Prosedur Penelitian (cetakan kelima belas). Jakarta: PT. Rineka Cipta.

Dinata, W. W., Haris, F., \& Padang, U. N. (2019). Tingkat Pemahaman Guru Penjas Terhadap Penerapan ELearning Dalam Proses Pembelajaran. Stamina, 2, 12-19.

Jatmika, H. M. (2010). Pemanfaatan Media Visual dalam Menunjang Pembelajaran Pendidikan Jasmani di Sekolah Dasar. Jurnal Pendidikan Jasmani Indonesia, 3(1), 89-99.

Setiawan, A. R., Puspaningrum, M., \& Umam, K. (2019). Pembelajaran Fiqh Mu’Āmalāt Berorientasi Literasi Finansial. TARBAWY: Indonesian Journal of Islamic Education, 6(2), 187-192. https://doi.org/10.17509/t.v6i2.20887

Sugiyono, P. D. (2013). Statistik untuk Penelitian. CV. Alvabeta Bandung.

Sugiyono, P. D. (2018). Metode penelitian kuantitatif kualitatif dan R\&D. xiii.

Ulinnuha, A. (2017). Tingkat pemahaman aktivitas renang pada siswa kelas XI sman 1 jogonalan klaten. Tingakat Pemahaman Aktivitas Renang, 1, 1-10.

Walangadi, H., \& Pratama, W. P. (2020). Meningkatkan Pemahaman Belajar Siswa Menggunakan Media Video Animasi 2D. Aksara: Jurnal Ilmu Pendidikan Nonformal, 4(3), 201-208.

Dipublikasikan Oleh :

UPT Publikasi dan Pengelolaan Jurnal

Universitas Islam Kalimantan Muhammad Arsyad Al-Banjari Banjarmasin 